\title{
Energy and tannin extract supplementation for dairy cows on annual winter pastures
}

\section{Suplementação com extrato tanífero e energia para vacas leiteiras em pasto anual de inverno}

\author{
Tiago Pansard Alves ${ }^{1}$; Kamila Maciel Dias ${ }^{1}$; Lucélia Janes Hans Dallastra ${ }^{2}$; \\ Bibiana Lima Fonseca ${ }^{2}$; Henrique Mendonça Nunes Ribeiro-Filho ${ }^{3 *}$
}

\begin{abstract}
Energy supplementation can increase the consumption of metabolizable energy and substrate for microbial growth, while condensed tannins aid in increasing the duodenal flow of metabolizable proteins. The objective of this study was to evaluate the effects of energy supplementation and the inclusion of tannin extract (TE) from Acacia mearnsii (Weibull Black, Tanac S. A., Montenegro, Brazil) on the production performance of dairy cows grazing on winter pastures. Nine multiparous Holstein cows in mid lactation were distributed in a $3 \times 3$ Latin square experimental design over three periods of 28 days (21 adaptation and 7 sampling). The treatments were: without supplementation (WS), supplementation with $4 \mathrm{~kg}$ of corn grain (CG), and corn grain $+80 \mathrm{~g}$ of tannin extract (TE). The dry matter (DM) intake from pastures was similar among treatments, but the consumption of DM of the supplement was higher in the CG treatment than that in the TE treatment. The total DM intake was higher for the supplemented animals $\left(17.3 \mathrm{~kg} \cdot \mathrm{day}^{-1}\right)$ than that for the unsupplemented animals $\left(14.9 \mathrm{~kg} \cdot \mathrm{day}^{-1}\right)$ and in the TE treatment $\left(17.7 \mathrm{~kg} \cdot\right.$ day $\left.^{-1}\right)$ than in the $\mathrm{CG}$ treatment $\left(16.7 \mathrm{~kg}\right.$ day $\left.^{-1}\right)$. Milk production increased from the unsupplemented to the supplemented animals ( 20.9 to $23.5 \mathrm{~kg}$, respectively), while the content of urea $\mathrm{N}$ in the milk decreased (12.6 to $10.5 \mathrm{mg} \cdot 100 \mathrm{~mL}^{-1}$, respectively). There were no differences in milk production or content of milk urea $\mathrm{N}$ between the $\mathrm{CG}$ and TE treatments. Energy supplementation is a tool for improving the nutritional profile and the performance of dairy cows in mid lactation grazing on annual winter pastures, while tannin extract aids in improving the energy balance.
\end{abstract}

Key words: Energy balance. Nutritional profile. Milk production. Condensed tannin.

\section{Resumo}

\begin{abstract}
A suplementação energética visa aumentar o consumo de energia metabolizável e de substrato para o crescimento microbiano, enquanto os taninos condensados são capazes de aumentar o fluxo duodenal de proteína metabolizável de origem alimentar. Objetivou-se avaliar o efeito da suplementação energética e da inclusão de extrato tanífero de Acacia mearnssi (Weibull Black, Tanac S. A., Montenegro, Brasil) no desempenho produtivo de vacas leiteiras em pasto de inverno. Foram utilizadas nove vacas multíparas da raça Holandês no terço médio de lactação, distribuídas num delineamento experimental em Quadrado latino $3 \times 3$, com três períodos de 28 dias (21 de adaptação e 7 de coleta). Os tratamentos foram sem suplementação (SS), suplementação com 4 kg de grão de milho (GM) e grão de milho + 80
\end{abstract}

\footnotetext{
${ }^{1}$ Discentes, Curso de Doutorado do Programa de Pós-Graduação em Ciência Animal, Lages, SC, Brasil. E-mail: tiagoalveszoot@ hotmail.com; kamila.dias@gmail.com

2 Discentes, Curso de Mestrado do Programa de Pós-Graduação em Ciência Animal, Lages, SC, Brasil. E-mail: luceliahans@ hotmail.com; ituimii@gmail.com

3 Prof., Dr., Universidade do Estado de Santa Catarina, UDESC, Centro de Ciências Agrárias, CAV, Programa de Pós-Graduação em Ciência Animal, Lages, SC, Brasil. E-mail: henrique.ribeiro@udesc.br

* Author for correspondence
} 
g de extrato tanífero (ET). O consumo de MS de pasto foi similar entre os tratamentos, mas o consumo de MS do suplemento foi superior nos animais do tratamento GM em comparação àqueles do tratamento ET. O consumo de MS total foi superior nos animais suplementados $\left(17,3 \mathrm{~kg} \mathrm{dia}^{-1}\right)$ em comparação aos não suplementados $\left(14,9 \mathrm{~kg} \mathrm{dia}^{-1}\right)$ e nos do tratamento ET $\left(17,7 \mathrm{~kg} \mathrm{dia}^{-1}\right)$ em comparação aos do tratamento GM (16,7 $\left.\mathrm{kg} \mathrm{dia}^{-1}\right)$. A produção de leite aumentou (de 20,9 para 23,5 kg) e o teor de $\mathrm{N}$ ureico no leite reduziu de 12,6 para $10,5 \mathrm{mg} 100 \mathrm{~mL}^{-1}$ nos animais suplementados em comparação aos não suplementados, mas não houve diferença entre os tratamentos GM e ET. A suplementação energética é uma ferramenta para a melhoria do perfil nutricional e do desempenho de vacas leiteiras no terço médio de lactação em pastos anuais de inverno, enquanto o extrato tanífero contribui para a melhoria do balanço energético.

Palavras-chave: Balanço energético. Perfil nutricional. Produção leiteira. Tanino condensado.

\section{Introduction}

The consumption of metabolizable energy is the main factor limiting milk production on pasture systems (PEYRAUD; DELAGARDE, 2013), and energy supplementation is a tool to ameliorate this deficiency. However, other factors, such as the supply of amino acids, become limiting factors in milk production for dairy cows with high yield potentials (>35 kg milk $\cdot \mathrm{day}^{-1}$ and $650 \mathrm{~kg}$ live weight, LW) (HILLS et al., 2015).

In a previous work, Ribeiro-Filho et al. (2007) found no effect of supplementation amount (2 or $4 \mathrm{~kg}$ of milled corn) on the milk production of Holstein cows with an average yield potential $(\approx 20$ $\mathrm{kg}$ milk $\cdot$ day $^{-1}$ ) grazing on annual ryegrass (Lolium multiflorum) pasture. The authors attributed this lack of response to supplementation to the quality of the forage and to the productive potential of the animals, which obtained all the nutrients required to meet their nutritional requirements at the lowest level of supplementation. However, a comparison of the responses to energy supplementation of dairy cows with average yield potential and the responses of animals fed only on annual winter pasture deserves further study.

Well-fertilized winter pastures, such as oat (Avena sativa) and annual ryegrass, are known to have high degradable protein levels in the rumen, which often exceed the demand of the rumen flora, causing increases in the excretion of $\mathrm{N}$ urea into the milk and urine. This results in a reduction in the efficiency of the use of feed $\mathrm{N}$
(COLMENERO; BRODERICK, 2006) and also negative environmental impacts (DIJKSTRA et al., 2013). Energy supplementation thereby increases the fermentable energy supply in the rumen, which may affect microbial growth (BACH et al., 2005), as well as the demand of $\mathrm{N}$ by microorganisms, reducing ruminal $\mathrm{N}$ losses. In contrast, the use of fodder with secondary components, such as condensed tannins (MIN et al., 2003), has proven to be a viable alternative for reducing the degradability of ruminal $\mathrm{N}$ and improving use efficiency.

Tannins are polyphenols with the ability to form complexes with proteins mainly by reducing their degradation in the rumen (PATRA; SAXENA, 2011). Therefore, tannins have been investigated as a food additive with the purpose of increasing the intestinal metabolizable protein flow. Ávila et al. (2015) studied Holstein steers receiving a diet consisting of corn silage $(70 \%)$ and protein concentrate (30\%). They observed that the inclusion of $15 \mathrm{~g}$ of Acacia mearnsii tannin extract per $\mathrm{kg}$ of DM increased the duodenal flow of non-ammonia $\mathrm{N}$ without affecting the duodenal flow of microbial protein, and reduced the urinary nitrogen excretion. However, the effects of including Acacia mearnsii tannin extract in the diet of dairy cows ingesting winter pasture have not yet been studied sufficiently.

The objective of this study was to evaluate the effects of energy supplementation and dietary inclusion of Acacia mearnsii tannin extract on the yield performance of dairy cows grazing on winter pasture. The hypothesis tested was that energy 
supplementation plus the tannin extract improves the energy and protein nutritional status of the animals, resulting in improvements in animal performance and reductions in milk urea $\mathrm{N}$ concentrations.

\section{Material and Methods}

\section{Treatments and experimental design}

The treatments evaluated were: oat pasture + ryegrass without supplementation (WS); oats + ryegrass with supplementation of $4 \mathrm{~kg}$ of corn grain (CG); and oat + ryegrass with supplementation of 4 $\mathrm{kg}$ corn grain plus $80 \mathrm{~g}$ of Acacia mearnsii tannin extract (Weibull Black, Tanac S. A., Montenegro, Brazil) (TE). The tannin extract was characterized by maintaining total tannins at a concentration of $694 \mathrm{~g} \cdot \mathrm{kg}^{-1}$ DM (KOZLOSKI et al., 2012). The cows were distributed in a $3 \times 3$ Latin square design for three periods of 28 days ( 21 for adaptation and 7 for collection).

\section{Site, animals, and experimental area}

The experiment was conducted in Lages, SC, Brazil $\left(27^{\circ} 47^{\prime} \mathrm{S}, 50^{\circ} 18^{\prime} \mathrm{W}\right.$; altitude $\left.920 \mathrm{~m}\right)$, during the spring of 2013. Nine Holstein cows were divided into three homogeneous groups according to milk production $(23.4 \pm 4.2 \mathrm{~kg})$, number of births $(3.8 \pm$ $1.2)$, days in milk (150 \pm 68 days), and body weight $(619 \pm 48 \mathrm{~kg})$.

The experimental area consisted of 6.5 ha of ryegrass (Lolium multiflorum cv. Barjumbo) + oat (Avena sativa cv. FAPA2), sown in April 2013. Four of the 6.5 ha were allocated to the adaptation periods and 2.25 ha were allocated for the collection periods. The animals were kept in the same paddock during the adaptation period, and separated by treatments during the collection periods. A 0.25 ha plot was allocated for each treatment per period. The strip grazing method was used, with a herbage allowance of $35 \mathrm{~kg}$ DM per day.

\section{Animal measurements}

Forage intake was measured as the difference between the biomass before and after grazing (LANTINGA et al., 2004) in each of the last 5 days of each experimental period. Milk production was measured in two daily milkings (7 a.m. and 4 p.m.). The samples for determining the milk composition were collected in two milkings during the last 4 days of each experimental period. Body weight was measured at the beginning of the experiment and at the end, and also at the beginning of each trial period. A total of $10 \mathrm{~mL}$ of blood from the jugular vein was collected in tubes without anticoagulant on the last day of each experimental period. The tubes were then centrifuged, and the plasma was cooled and stored at $-80^{\circ} \mathrm{C}$ for later analysis of nonesterified fatty acids (NEFA).

\section{Pasture and supplement measurements}

The herbage mass above ground level was estimated using a rising plate meter (Farmworks ${ }^{\circledR}$, F200 model, New Zealand), which was calibrated by accounting for the amount of DM present in the plate diameter $\left(0.1 \mathrm{~m}^{2}\right)$. Samples from 15 points (five per treatment), from a range of sward height across the total pasture area, were cut in each experimental period for calibration. The total herbage mass was cut at the soil level and oven dried with forced ventilation at $60^{\circ} \mathrm{C}$ for $48 \mathrm{~h}$ for each site. Regression equations were developed to estimate the herbage mass ( $\mathrm{kg} \mathrm{DM} \mathrm{ha-1)}$ as a function of the compressed height $(\mathrm{cm})$. At the end of the experiment, the equations were recalculated using an equation to estimate the herbage mass before grazing $\left(\mathrm{R}^{2}=\right.$ $0.89)$ and another for estimating herbage mass after grazing $\left(\mathrm{R}^{2}=0.79\right)$. The average compressed height of each paddock was calculated from at least 100 readings.

The morphological composition was determined by manually separating the fractions of leaves, stems, and dead material of the ryegrass and oat plants. In all evaluation periods, twenty fistfuls 
of grass, with an approximate diameter of $10 \mathrm{~cm}$ each, were collected by cutting with scissors to ground level before grazing. A subsample was used to determine the morphological composition and another to perform chemical bromatological analyses. The latter sub-sample was cut to the average height of the tiller after grazing, which was measured with a graduated scale for 300 tillers per paddock. The upper fraction, along with samples of the offered supplement and supplement leftovers, were dried in an oven with forced ventilation at $60^{\circ} \mathrm{C}$ for $48 \mathrm{~h}$ and then stored for further analysis. The height of the extended tillers was measured before and after grazing in the last 4 days of each experimental period.

\section{Laboratory analysis and nutritional value}

The chemical composition of the forage samples was determined for samples dried in an oven with forced ventilation at $60^{\circ} \mathrm{C}$ for $48 \mathrm{~h}$ and milled to the size of $1.0 \mathrm{~mm}$. The total DM was determined by drying at $105^{\circ} \mathrm{C}$ until reaching a constant weight, and mineral matter (MM) was determined by burning in a muffle furnace at $550^{\circ} \mathrm{C}$ for $4 \mathrm{~h}$. The total $\mathrm{N}$ content was determined by the Kjeldahl method (method 984.13, AOAC, 1997). The neutral detergent fiber content (NDF) was determined without using sodium sulfite, following Mertens (2002). The acid detergent fiber content (ADF) was determined according to the AOAC method (method 973.18) (AOAC, 1997), without using asbestos. The NEFA analysis was performed from blood plasma, using commercial kits (Wako NEFA-HR, Wako Chemicals EUA®, Richmond, EUA and BHBA: Ranbut, Randox ${ }^{\circledR}$ Laboratories Ltd, UK) according to the method described by Ballou et al. (2009). The net energy for lactation $\left(\mathrm{NE}_{1}\right)$ and the true protein values digestible in the intestine were calculated from the chemical composition of the forage samples and the supplements, using the equations proposed by INRA (2007). These calculations were performed by taking into account that the microbial synthesis in the rumen is limited by energy (PDIE), but also by considering that microbial synthesis in the rumen is limited by nitrogen (PDIN).

\section{Statistical analysis}

Data were subjected to analysis of variance using the PROC MIXED (SAS Institute, 1999). The variables linked to milk production, milk composition, and blood components were analyzed accounting for the fixed effects of the treatment, the random effects of the animals, and time $(\mathrm{n}=$ 9). The fixed effects of treatment and the random effects of the lot and period $(n=3)$ were taken into account for the characteristics of pasture and consumption. Treatments were compared using orthogonal contrast for treatment WS $\times$ the mean of the supplemented treatments (CG and TE), and treatment $\mathrm{CG} \times$ treatment $\mathrm{TE}$.

\section{Results and Discussion}

The average pre-grazing herbage mass, irrespective of the treatments, was about $2600 \mathrm{~kg}$ $\mathrm{DM} \cdot \mathrm{ha}^{-1}$ with an average height of $26.7 \mathrm{~cm}$ and approximately $50 \%$ leaf blades (Table 1). The average levels of crude protein (CP) and NDF of the consumed pasture were 173 and $540 \mathrm{~g} \cdot \mathrm{kg}^{-1} \mathrm{DM}$, respectively. The average concentrations of $\mathrm{NE}_{1}$ and metabolizable protein in the pasture of the three treatments were $6.63 \mathrm{MJ} \cdot \mathrm{kg}^{-1} \mathrm{DM}$ and $92 \mathrm{~g} \cdot \mathrm{kg}^{-1}$ $\mathrm{DM}$, respectively (Table 1$)$. The herbage allowance was $35.3 \mathrm{~kg} \cdot \mathrm{DM}$ cow $\cdot$ day $^{-1}$ (Table 2 ). 
Table 1. Pre-grazing characteristics for mixed pastures of oat (Avena sativa) and annual ryegrass (Lolium multiflorum Lam.) grazed upon by dairy cows without supplementation (WS) or supplemented with corn grain (CG) or corn grain $+80 \mathrm{~g}$ of the tannin extract of Acacia mearnsii (TE).

\begin{tabular}{|c|c|c|c|c|c|c|}
\hline \multirow{2}{*}{ Item } & \multicolumn{3}{|c|}{ Treatment } & \multicolumn{3}{|c|}{ Contrast (P value) } \\
\hline & WS & $\mathrm{CG}$ & $\mathrm{TE}$ & $\mathrm{CV}^{1}$ & $\mathrm{WS} \times \mathrm{S}^{2}$ & $\mathrm{CG} \times \mathrm{TE}$ \\
\hline Herbage mass $\left(\mathrm{kg} \mathrm{DM} \cdot \mathrm{ha}^{-1}\right)$ & 2636 & 2693 & 2461 & 14.1 & 0.712 & 0.251 \\
\hline \multicolumn{7}{|l|}{ Sward height $(\mathrm{cm})$} \\
\hline Rising plate meter & 27.1 & 27.7 & 25.3 & 14.6 & 0.712 & 0.251 \\
\hline Extended tiller & 32.8 & 32.3 & 31.2 & 13.6 & 0.611 & 0.605 \\
\hline Sheath & 15.4 & 17.2 & 14.5 & 8.8 & 0.460 & 0.014 \\
\hline Leaf blade & 17.4 & 15.1 & 16.7 & 24.0 & 0.419 & 0.440 \\
\hline \multicolumn{7}{|c|}{ Morphological composition $\left(\mathrm{g} \cdot \mathrm{kg}^{-1} \mathrm{DM}\right)$} \\
\hline Leaf blade & 461 & 453 & 525 & 14.9 & 0.387 & 0.098 \\
\hline Culm + sheath & 380 & 417 & 369 & 11.3 & 0.493 & 0.078 \\
\hline Dead material & 66 & 45 & 40 & 68.5 & 0.166 & 0.782 \\
\hline \multicolumn{7}{|c|}{ Chemical composition $\left(\mathrm{g} \cdot \mathrm{kg}^{-1} \mathrm{DM}\right)$} \\
\hline Dry matter $\left(\mathrm{g} \cdot \mathrm{kg}^{-1}\right.$ green $)$ & 14.8 & 14.3 & 15.5 & 13.1 & 0.906 & 0.258 \\
\hline Organic matter & 910 & 919 & 920 & 0.2 & 0.256 & 0.938 \\
\hline Crude protein & 168 & 185 & 165 & 1.0 & 0.406 & 0.069 \\
\hline Neutral detergent fiber & 539 & 550 & 532 & 3.6 & 0.809 & 0.118 \\
\hline Acid detergent fiber & 252 & 255 & 253 & 7.5 & 0.781 & 0.867 \\
\hline \multicolumn{7}{|l|}{ Nutritional value } \\
\hline $\mathrm{NE}_{\mathrm{L}} \cdot \mathrm{MJ} \cdot \mathrm{kg}^{-1} \mathrm{MS}^{3}$ & 6.57 & 6.70 & 6.62 & 2.7 & 0.342 & 0.469 \\
\hline PDIN. $g \cdot \mathrm{kg}^{-1} \mathrm{MS}^{4}$ & 105 & 115 & 103 & 9.5 & 0.412 & 0.068 \\
\hline PDIE. $\mathrm{g} \cdot \mathrm{kg}^{-1} \mathrm{MS}^{5}$ & 91.8 & 92.1 & 92.0 & 1.2 & 0.590 & 0.889 \\
\hline
\end{tabular}

${ }^{1}$ Coefficient of variation; ${ }^{2}$ Comparison between unsupplemented and supplemented animals (mean of the CG and TE treatments); ${ }^{3}$ Net energy for lactation estimated according to INRA (2007); ${ }^{4}$ True protein digestible in the intestine, considering that the microbial synthesis in the rumen is limited by nitrogen (INRA, 2007); ${ }^{5}$ True protein digestible in the intestine considering that the microbial synthesis in the rumen is limited by energy (INRA, 2007).

The forage characteristics and the management practices precluded the main objective of this study because the supply of forage had a curvilinear effect on consumption (PEYRAUD et al., 1996), where levels above $35 \mathrm{~kg} \mathrm{DM} \cdot$ day $^{-1}$ had little effect on the individual DM consumption, with a significant reduction in productivity per area (PÉREZPRIETRO; DELAGARDE, 2013). The intake rate was greatest when the grass height exceeded $20 \mathrm{~cm}$ (DELAGARDE et al., 2011) and the proportion of leaves only significantly affected the intake rate values when their values fell below $37 \%$ of the total
DM (GUZATTI, 2013). The observed leaf removal ratio also indicated that there was a quantitative restriction on consumption, after a reduction of approximately $42 \%$ of the height from the input point and after approximately $41 \%$ of the original forage mass was eaten. Overall, the consumption ability of dairy cows was enhanced when the residual height of winter pastures was greater than or equal to $50 \%$ of the initial height (DELAGARDE et al., 2006). In this experiment, the average residual height was approximately $58 \%$ of the initial height. 
Table 2. Grazing management, post-pasture characteristics, and post-grazing characteristics of mixed pastures of oat (Avena sativa) and annual ryegrass (Lolium multiflorum Lam.) grazed upon by dairy cows without supplementation (WS), supplemented with corn grain (CG) or corn grain $+80 \mathrm{~g}$ of the Acacia mearnsii tannin extract (TE).

\begin{tabular}{|c|c|c|c|c|c|c|}
\hline \multirow{2}{*}{ Item } & \multicolumn{3}{|c|}{ Treatment } & \multicolumn{3}{|c|}{ Contrast (P value) } \\
\hline & WS & CG & TE & $\mathrm{CV}^{1}$ & $\mathrm{WS} \times \mathrm{S}^{2}$ & $\mathrm{CG} \times \mathrm{TE}$ \\
\hline Herbage mass $\left(\mathrm{kg} \mathrm{DM} \cdot \mathrm{ha}^{-1}\right)$ & 1550 & 1585 & 1471 & 5.4 & 0.544 & 0.042 \\
\hline \multicolumn{7}{|l|}{ Sward height $(\mathrm{cm})$} \\
\hline Rising plate meter & 15.6 & 16.0 & 14.7 & 11.9 & 0.542 & 0.042 \\
\hline Extended tiller & 18.3 & 18.8 & 18.9 & 15.6 & 0.654 & 0.983 \\
\hline Sheath & 9.9 & 9.5 & 10.1 & 23.5 & 0.959 & 0.632 \\
\hline Leaf blade & 8.4 & 9.3 & 8.8 & 16.6 & 0.359 & 0.482 \\
\hline \multicolumn{7}{|c|}{ Herbage allowance $\left(\mathrm{kg} \mathrm{DM} \cdot\right.$ day $\left.^{-1}\right)$} \\
\hline Total DM & 35.3 & 35.3 & 35.3 & 0.4 & 0.321 & 0.831 \\
\hline Green material & 29.6 & 30.7 & 31.6 & 3.7 & 0.030 & 0.194 \\
\hline Leaf blade & 16.2 & 16.0 & 18.5 & 14.6 & 0.364 & 0.096 \\
\hline Offered area $\left(\mathrm{m}^{2} \cdot \mathrm{cow} \cdot\right.$ day $\left.^{-1}\right)$ & 137 & 144 & 147 & 19.1 & 0.503 & 0.841 \\
\hline
\end{tabular}

The ingested pasture quality can be qualitatively classified as average to good based on its energy value. This would allow an intake of up to $17 \mathrm{~kg}$ $\mathrm{DM} \cdot \mathrm{day}^{-1}$ for high potential productive cows in the absence of quantitative or structural restrictions (PEYRAUD; DELAGARDE, 2013). In addition, the protein content is within the range described in experiments using ryegrass pastures in the same experimental area (168 to $196 \mathrm{~g} \cdot \mathrm{kg}^{-1} \mathrm{DM}$ ) in previous years (MIGUEL et al., 2014; RIBEIROFILHO et al.,2007, 2009a).

The forage DM intake was similar between treatments $\left(\right.$ mean $=14.3 \mathrm{~kg} \cdot$ day $\left.^{-1}\right)$, but the DM intake of the supplement was higher $(\mathrm{P}<0.05)$ in the CG treatment compared to that for the TE treatment. The total DM intake was higher for the supplemented animals $(\mathrm{P}<0.001)$ than for the unsupplemented animals and for the animals with the TE treatment than those with the CG treatment $(\mathrm{P}<0.05)$. The substitution rate $(\mathrm{kg} \mathrm{DM}$ of forage ingested minus / $\mathrm{kg}$ DM of supplement consumed) was 0.45 in the CG treatment and close to zero in the TE treatment, which indicated a higher total DM intake $(\mathrm{P}<0.05)$ for animals fed with corn grain and tannin extract than that for animals that received grain without extract.

The substitution rate observed in the CG treatment is consistent with those observed in dairy cows grazed on pastures with high herbage allowance (BARGO et al., 2002). In other words, the low substitution rate observed in the TE treatment can be explained by the lower intake of supplement (MCEVOY et al., 2008) and/or by the action of condensed tannins in the rumen. The reduction of supplement ingestion resulting from the inclusion of Acacia mearnsii tannin extract has been previously reported by other authors (GRIFFITHS et al., 2013). Tannins have also been associated with a reduction in ruminal degradation of organic matter (OM) (ÁVILA et al., 2015; KOZLOSKI et al., 2012), and proteins and fibrous carbohydrates (ORLANDI et al., 2015). The fibrous carbohydrates that escape from ruminal fermentation have low post-ruminal digestibility, causing a reduction in the consumption of the digestible $\mathrm{OM}$ and of liquid energy per $\mathrm{kg}$ of ingested DM. Therefore, the lowest substitution rate recorded in the TE treatment may have been the result of a mechanism for maintaining the 
daily energy intake, once the foods with high OM digestibility, such as the pastures used in this study, have rumen fill with lower importance in regulating consumption (KETELAARS; TOLKAMP, 1992).

Milk production was higher $(\mathrm{P}<0.01)$ in the supplemented animals than it was in the unsupplemented animals $\left(+2.6 \mathrm{~kg} \cdot \mathrm{day}^{-1}\right)$, but it did not vary with the inclusion of tannin extract compared to the supplementation exclusively with the energy concentrate (Table 3). These results can be explained by the increase in liquid energy obtained exclusively from the pasture, which was not enough to meet the nutritional needs of dairy cows with $620 \mathrm{~kg}$ of LW producing $21 \mathrm{~kg}$ milk $\cdot$ day $^{-1}$, resulting in a negative energy balance and higher concentration of NEFA in the blood of animals that did not receive supplementation. These results corroborate the findings of Ribeiro-Filho et al. (2009b) who reported that dairy cows in pastures with abundant annual ryegrass produced the equivalent to the animals in this study, sustaining a positive energy balance. However, the cows used by the aforementioned authors were lighter (532 \pm 56.5 $\mathrm{kg}$ ) and the pasture used had higher CP contents and lower NDF contents than the ones in this study. In addition, the pasture used by Ribeiro-Filho et al. (2009a), had characteristics that probably contributed to a higher daily intake of pasture (16.6 $\mathrm{kg}$ DM) than those in this study.

Table 3. Dry matter intake, productive performance, and energy balance of dairy cows in mixed pastures of oat (Avena sativa) and annual ryegrass (Lolium multiflorum Lam.) without supplementation (WS) or supplemented with corn (CG) or corn grain $+80 \mathrm{~g}$ of the Acacia mearnsii tannin extract (TE).

\begin{tabular}{|c|c|c|c|c|c|c|}
\hline \multirow{2}{*}{ Item } & \multicolumn{3}{|c|}{ Treatment } & \multicolumn{3}{|c|}{ Contrast (P value) } \\
\hline & WS & CG & TE & $\mathrm{CV}^{1}$ & $\mathrm{WS} \times \mathrm{S}^{2}$ & $\mathrm{CG} \times \mathrm{TE}$ \\
\hline \multicolumn{7}{|l|}{ Dry matter intake $\left(\mathrm{kg} \mathrm{day}^{-1}\right)$} \\
\hline Forage & 14.9 & 13.4 & 14.7 & 19.5 & 0.501 & 0.367 \\
\hline Supplement & 0.00 & 3.33 & 3.02 & 6.6 & $<0.001$ & 0.013 \\
\hline Total & 14.9 & 16.7 & 17.7 & 6.0 & $<0.001$ & 0.044 \\
\hline Milk production $\left(\mathrm{kg} \cdot \mathrm{day}^{-1}\right)$ & 20.9 & 23.7 & 23.4 & 11.7 & 0.001 & 0.739 \\
\hline 4\% FCM production $\left(\mathrm{kg} \cdot \text { day }^{-1}\right)^{3}$ & 17.9 & 20.1 & 19.4 & 13.6 & 0.009 & 0.340 \\
\hline \multicolumn{7}{|l|}{ Milk composition } \\
\hline Fat $(\%)$ & 3.07 & 3.04 & 2.94 & 174 & 0.550 & 0.502 \\
\hline Protein $(\%)$ & 3.38 & 3.39 & 3.37 & 53.8 & 0.928 & 0.639 \\
\hline Casein $(\%)$ & 2.61 & 2.63 & 2.61 & 55.6 & 0.765 & 0.606 \\
\hline Urea nitrogen $\left(\mathrm{mg} 100 \mathrm{~mL}^{-1}\right)$ & 12.6 & 10.4 & 10.6 & 19.5 & 0.002 & 0.854 \\
\hline Fat production $\left(\mathrm{g} \cdot\right.$ day $\left.^{-1}\right)$ & 635 & 710 & 670 & 19.5 & 0.095 & 0.273 \\
\hline Protein production $\left(\mathrm{g} \cdot\right.$ day $\left.^{-1}\right)$ & 698 & 800 & 785 & 12.6 & 0.001 & 0.572 \\
\hline Live weight (kg) & 621 & 622 & 622 & 2.4 & 0.817 & 0.852 \\
\hline Consumed $\mathrm{NE}_{\mathrm{L}}\left(\mathrm{MJ} \cdot \text { day }^{-1}\right)^{4}$ & 96.9 & 113 & 120 & 5.6 & $<0.001$ & 0.036 \\
\hline Consumed MP $\left(\mathrm{kg} \cdot \mathrm{day}^{-1}\right)^{5}$ & 1.33 & 1.52 & 1.58 & 65.0 & 0.001 & 0.194 \\
\hline Energy balance $\left(\mathrm{MJ} \cdot \text { day }^{-1}\right)^{6}$ & -2.69 & 6.57 & 15.5 & 131 & 0.014 & 0.042 \\
\hline Protein balance $\left(\mathrm{kg} \cdot \text { day }^{-1}\right)^{7}$ & -0.07 & 0.00 & 0.13 & 8550 & 0.074 & 0.142 \\
\hline $\operatorname{NEFA}\left(\mathrm{mmol} \cdot \mathrm{L}^{-1}\right)^{8}$ & 0.37 & 0.29 & 0.27 & 24.1 & $<0.001$ & 0.698 \\
\hline
\end{tabular}

${ }^{1}$ Coefficient of variation; ${ }^{2}$ Comparison between unsupplemented and supplemented animals (mean of the CG and TE treatments); ${ }^{3}$ Milk production corrected to $4 \%$ fat; ${ }^{4} \mathrm{Net}$ energy for lactation; ${ }^{5}$ Metabolizable protein; ${ }^{6}$ Calculated as the difference between $\mathrm{NE}_{\mathrm{L}}$ consumption minus the requirements for $\mathrm{NE}_{\mathrm{L}}{ }^{7}$ Calculated as the difference between MP consumption minus the MP requirements; ${ }^{8}$ Non-esterified fatty acids in the blood. 
Supplement supply caused a $\mathrm{NE}_{1}$ increase of approximately $20 \mathrm{MJ} \cdot$ day $^{-1}$, leading to increased milk and protein production. The best diet balance in the supplementation treatments resulted in the reduction in blood contents of NEFA as well as in the reduction in the milk urea nitrogen (MUN) concentration. The existence of negative correlations between NEFA concentration in the blood and the energy balance of dairy cows (REIST et al., 2002), and between MUN and the efficiency of converting the consumed protein into true milk protein (NOUSIAINEN et al., 2004), are well documented in the literature.

The lack of effects of tannin extract on milk production and on the efficiency of using $\mathrm{N}$ may be explained by the protein contents of the pasture $(\approx$ $\left.160 \mathrm{~g} \cdot \mathrm{kg}^{-1} \mathrm{DM}\right)$ and yield potential of the animal. The protein balance (consumption of metabolizable protein - requirement of metabolizable protein) did not differ between treatments, and had near-zero values (Table 3). These results confirm that it is not necessary to provide protein supplementation to dairy cows in winter pastures with protein contents of approximately $160 \mathrm{~g} \cdot \mathrm{kg}^{-1} \mathrm{DM}$ and productive potential between 20 and $25 \mathrm{~kg}$ of milk per day. The protein contents of the pasture are directly related to its use efficiency, as ruminal nitrogen loss depends on the $\mathrm{CP}$ content of the diet. The increase in the CP contents of the diet is associated with the concentrations of ammonia in the rumen and of urea in the blood, and with the increase of urea excretion into the urine and milk (COLMENERO; BRODERICK, 2006). In the present study, the higher values of true digestible protein considering that the microbial synthesis in the rumen was limited more by PDIN of the pasture than by PDIE (Table 1) indicated that the quantity of the rumen degradable protein intake in animals without supplementation was greater than the availability of energy for microbial growth (INRA, 2007). The excess intake of degradable nitrogen would cause urea nitrogen losses in milk and urine. Therefore, a search for a balance between the PDIE and PDIN contents is recommended (FAVERDIN et al., 2003). The use of protein supplementation in the conditions tested in this experiment would likely result in lower efficiency in using consumed nitrogen, with no responses in milk production compared to energy supplementation.

\section{Conclusions}

Energy supplementation is a tool for improving the nutritional profile of dairy cows in oat and ryegrass pastures, resulting in an increase in the total consumption of DM, an increase in productive performance, and reduction in nitrogen urea content of the milk. Including tannin extract from Acacia mearnsii did not improve the productive performance of these animals, but it did help reduce the substitution rate and improve the energy balance of cows in mid-lactation. Future studies should be conducted to evaluate the effects of tannin extract on animals of higher production potential, and on the profile of milk fatty acids.

\section{Acknowledgements}

The authors thank CAPES and CNPq for the doctoral fellowships and research productivity provided to the first and last authors, respectively.

\section{References}

ÁVILA, S. C.; KOZLOSKI, G. V.; ORLANDI, T.; MEZZOMO, M. P.; STEFANELLO, S. Impact of a tannin extract on digestibility, ruminal fermentation and duodenal flow of amino acids in steers fed maize silage and concentrate containing soybean meal or canola meal as protein source. The Journal of Agricultural Science, Cambridge, v. 153, n. 5, p. 943-953, 2015.

ASSOCIATION OF OFFICIAL ANALYTICAL CHEMISTS - OAC. Official methods of analysis. $16^{\text {th }}$ ed. Washington: W. Horwitz, 1997. 850 p. 
BACH, A.; CALSAMIGLIA, S.; STERN, M. D. Nitrogen Metabolism in the Rumen. Journal of Dairy Science, Champaign, v. 88, n. 2004, p. E9-E21, 2005.

BALLOU, M. A.; GOMES, R. C.; JUCHEM, S. O.; DEPETERS, E. J. Effects of dietary supplemental fish oil during the peripartum period on blood metabolites and hepatic fatty acid compositions and total triacylglycerol concentrations of multiparous Holstein cows. Journal of Dairy Science, Champaign, v. 92, n. 2, p. 657-669, 2009.

BARGO, F.; MULLER, L. D.; DELAHOY, J. E.; CASSIDY, T. W. Milk response to concentrate supplementation of high producing dairy cows grazing at two pasture allowances. Journal of Dairy Science, Champaign, v. 85, n. 7, p. 1777-1792, 2002.

COLMENERO, J. J. O.; BRODERICK, G. A. Effect of dietary crude protein concentration on milk production and nitrogen utilization in lactating dairy cows. Journal of Dairy Science, Champaign, v. 89, n. 5, p. 1704-1712, 2006.

DELAGARDE, R.; DELABY, L.; FAVERDIN, P. Diet formulation for grazing dairy cows. In: rencontres autour des recherches sur les ruminants, 13., 2006, Paris. Proceedings... Paris: INRA/Institut de l'Elevage, 2006. p. 89-92.

DELAGARDE, R.; FAVERDIN, P.; BARATTE, C.; PEYRAUD, J. L. GrazeIn: A model of herbage intake and milk production for grazing dairy cows. 2. Prediction of intake under rotational and continuously stocked grazing management. Grass and Forage Science, Malden, v. 66, n. 1, p. 45-60, 2011.

DIJKSTRA, J.; OENEMA, O.; VAN GROENIGEN, J. W.; SPEK, J. W.; VAN VUUREN, A. M.; BANNINK, A. Diet effects on urine composition of cattle and $\mathrm{N} 2 \mathrm{O}$ emissions. Animal, Cambridge, v. 7, n. s2, p. 292-302, 2013.

FAVERDIN, P.; M'HAMED, D.; RICO-GOMEZ, M.; VÉRITÉ, R. La nutrition azotée influence l'ingestion chez la vache laitière. INRA Productions Animales, SaintGenès-Champanelle, v. 16, n. 1, p. 27-37, 2003.

GRIFFITHS, W. M.; CLARK, C. E. F.; CLARK, D. A.; WAGHORN, G. C. Supplementing lactating dairy cows fed high-quality pasture with black wattle (Acacia mearnsii) tannin. Animal, Cambridge, v. 7, n. 11, p. 17891795, 30 nov. 2013.

GUZATTI, G. C. Taxa de ingestão de forragem em pastos de aveia e azevém em cultivo puro ou consorciados. 2013. Dissertação (Mestrado em Ciência Animal) - Centro de Ciências Agroveterinárias, Universidade do Estado de Santa Catarina, Lages.
HILLS, J. L.; WALES, W. J.; DUNSHEA, F. R.; GARCIA, S. C.; ROCHE, J. R. Invited review: An evaluation of the likely effects of individualized feeding of concentrate supplements to pasture-based dairy cows. Journal of Dairy Science, Champaign, v. 98, n. 3, p. 1363-1401, 2015.

INSTITUT NATIONAL DE LA RECHERCHE AGRICOLE - INRA. Alimentation des bovins, ovins et caprins: Besoins des animaux-Valeurs des aliments. Versailles: Quae, 2007.311 p.

KETELAARS, J. J. M. H.; TOLKAMP, B. J. Toward a new theory of feed intake regulation in ruminants 1 . Causes of differences in voluntary feed intake: critique of current views. Livestock Production Science, Amsterdam v. 30, n. 4, p. 269-296, 1992.

KOZLOSKI, G. V.; HÄRTER, C. J.; HENTZ, F.; ÁVILA, S. C. de; ORLANDI, T.; STEFANELLO, C. M. Intake, digestibility and nutrients supply to wethers fed ryegrass and intraruminally infused with levels of Acacia mearnsii tannin extract. Small Ruminant Research, Amsterdam, v. 106, n. 2-3, p. 125-130, 2012.

LANTINGA, E. A.; NEUTEBOOM, J. H.; MEIJS, J. A. C. Sward methods. In: PENNING, P. D. (Ed.). Herbage intake handbook. $2^{\text {th }}$ ed. Maidenhead: The British Grassland Society, 2004. p. 1-191.

MCEVOY, M.; KENNEDY, E.; MURPHY, J. P.; BOLAND, T. M.; DELABY, L.; O'DONOVAN, M. The effect of herbage allowance and concentrate supplementation on milk production performance and dry matter intake of spring-calving dairy cows in early lactation. Journal of Dairy Science, Champaign, v. 91, n. 3, p. 1258-1269, 2008.

MERTENS, D. R. Gravimetric determination of amylasetreated neutral detergent fibre in feeds with refluxing beakers or crucibles: a collaborative study. Journal of AOAC International, Rockville, v. 85, n. 6, p. 1217-1240, 2002.

MIGUEL, M.F.; RIBEIROFILHO,H.M.N.;ANDRADE, E. A. de; GENRO, T. C. M.; DELAGARDE, R. Pasture intake and milk production of dairy cows grazing annual ryegrass with or without corn silage supplementation. Animal Production Science, Melbourne, v. 54, n. 10, p. 1810-1816, 2014.

MIN, B.; BARRY, T.; ATTWOOD, G.; MCNABB, W. The effect of condensed tannins on the nutrition and health of ruminants fed fresh temperate forages: a review. Animal Feed Science and Technology, Amsterdam, v. 106, n. 1-4, p. 3-19, 2003. 
NOUSIAINEN, J.; SHINGFIELD, K. J.; HUHTANEN, P. Evaluation of milk urea nitrogen as a diagnostic of protein feeding. Journal of Dairy Science, Champaign, v. 87, n. 2, p. 386-398, 2004.

ORLANDI, T.; KOZLOSKI, G. V.; ALVES, T. P.; MESQUITA, F. R.; ÁVILA, S. C. Digestibility, ruminal fermentation and duodenal flux of amino acids in steers fed grass forage plus concentrate containing increasing levels of Acacia mearnsii tannin extract. Animal Feed Science and Technology, Amsterdam, v. 210, p. 37-45, 2015.

PATRA, A. K.; SAXENA, J. Exploitation of dietary tannins to improve rumen metabolism and ruminant nutrition. Journal of the Science of Food and Agriculture, Malden, v. 91, n. 1, p. 24-37, 2011.

PÉREZ-PRIETO, L. A.; DELAGARDE, R. Metaanalysis of the effect of pasture allowance on the pasture intake, milk production, and grazing behavior of dairy cows grazing temperate grasslands. Journal of Dairy Science, Champaign, v. 96, n. 10, p. 6671-6964, 2013.

PEYRAUD, J. L.; COMERON, E. A.; WADE, M. H.; LEMAIRE, G.; PEYRAUD, J. L.; COMERON, E. A.; WADE, M. H. The effect of daily herbage allowance, herbage mass and animal factors upon herbage intake by grazing dairy cows. Annales de Zootechnie, Les Ulis, v. 45, n. 3, p. 201-217, 1996.

PEYRAUD, J. L.; DELAGARDE, R. Managing variations in dairy cow nutrient supply under grazing. Animal, Cambridge, v. 7, n. s1, p. 57-67, 2013.
REIST, M.; ERDIN, D.; VON EUW, D.; TSCHUEMPERLIN， K.; LEUENBERGER, H.; CHILLIARD, Y.; HAMMON, H. M.; MOREL, C.; PHILIPONA, C.; ZBINDEN, Y.; KUENZI, N.; BLUM, J. W. Estimation of energy balance at the individual and herd level using blood and milk traits in high-yielding dairy cows. Journal of Dairy Science, Champaign, v. 85, n. 12, p. 3314-3327, 2002.

RIBEIRO-FILHO, H. M. N.; GIACOMET, C. D.; DIAS, K. M.; CRESTANI, S.; SETELICH, E. A.; THALER NETO, A. Farelo de glúten de milho para vacas leiteiras em pastos de azevém anual. Ciência Rural, Santa Maria, v. 39, n. 4, p. 1162-1168, 2009a.

RIBEIRO-FILHO, H. M. N.; HEYDT, M. S.; BAADE, E. A. S.; THALER NETO, A. Consumo de forragem e produção de leite de vacas em pastagem de azevémanual com duas ofertas de forragem. Revista Brasileira de Zootecnia, Viçosa, MG, v. 38, n. 10, p. 2038-2044, $2009 \mathrm{~b}$.

RIBEIRO-FILHO, H. M. N.; SEMMELMANN, C. E. N.; HEYDT, M. S.; THALER NETO, A. Suplementação energética para vacas leiteiras pastejando azevém com alta oferta de forragem. Revista Brasileira de Zootecnia, Viçosa, MG, v. 36, n. 6, p. 2152-2158, 2007.

STATISTICAL ANALYSIS SYSTEM - SAS Instituite. User's Guide: Statistics. Cary: SAS Institute, 1999. 